\title{
A density functional theory study of reactions of relevance to catalytic hydrocarbon synthesis and combustion
}

\author{
Mina Arya ${ }^{1,2}$ - Joakim Niklasson ${ }^{1} \cdot$ Abas Mohsenzadeh $^{1} \cdot$ Kim Bolton $^{1}$
}

Received: 25 June 2018 / Accepted: 25 September 2018 / Published online: 17 October 2018

(c) The Author(s) 2018

\begin{abstract}
Synthesis and combustion of hydrocarbons on a series of metal surfaces ( $\mathrm{Ag}, \mathrm{Au}, \mathrm{Al}, \mathrm{Cu}, \mathrm{Rh}, \mathrm{Pt}$ and $\mathrm{Pd}$ ) were investigated using density functional theory (DFT). The adsorption energies for all species involved in these reactions, as well as the reaction energies and activation barriers on these surfaces, were calculated using the same models and DFT methods. The results were used to test the validity of the Brønsted-Evans-Polanyi (BEP) and transition state scaling (TSS) relationships for these reactions on these metal surfaces. The BEP relationship appears to be a valid indicator for the synthesis reactions with $R^{2}$ values of $0.83,0.88$ and 0.94 for $\mathrm{CO}$ dissociation, $\mathrm{CO}$ hydrogenation and formyl (CHO) dissociation to $\mathrm{CH}+\mathrm{O}$, respectively. In addition to $\mathrm{CH}$ splitting, which has been studied before, the BEP relationship also appears to be valid for the $\mathrm{CH}$ oxidation and $\mathrm{CHO}$ dissociation to $\mathrm{CO}+\mathrm{H}$ combustion reactions with $R^{2}$ values of $0.94,0.89$ and 0.88 , respectively. Also, the TSS relationship is excellent with a $R^{2}$ value of 1 for all synthesis and combustion reactions. The BEP and TSS relationships were subsequently used to estimate the energetics of the synthesis and combustion reactions on $\mathrm{Ni}$, $\mathrm{Co}$ and $\mathrm{Fe}$ surfaces. The results reveal that the transition state energies estimated by the TSS relationships are in better agreement with data obtained from DFT calculations than the activation energies estimated by the BEP relationships. Therefore, the TSS relationship is preferred when predicting energetics of these reactions on these surfaces.
\end{abstract}

Keywords Density functional theory · Hydrocarbon synthesis · Hydrocarbon combustion · Brønsted-Evans-Polanyi · Transition state scaling · Catalyst

Electronic supplementary material The online version of this article (https://doi.org/10.1007/s00214-018-2339-4) contains supplementary material, which is available to authorized users.

Mina Arya

mina.arya@hb.se

Joakim Niklasson

s161931@ student.hb.se

Abas Mohsenzadeh

abas.mohsenzadeh@hb.se

Kim Bolton

kim.bolton@hb.se

1 Swedish Centre for Resource Recovery, University of Borås, 501-90 Borås, Sweden

2 Department of Chemistry, University of Sistan and Baluchestan, Zahedan 98135-674, Iran

\section{Introduction}

The interactions between atomic or molecular species and metal surfaces are fundamental to surface chemistry [1], and the field of modern theoretical surface science provides an opportunity to investigate adsorbates and surface structures on the microscopic scale. The insight gained at this scale has useful applications in industrial technologies, including the search for more efficient catalysts [2]. There are numerous reviews and articles which deal with adsorption of small molecules and radicals on metal surfaces, from both experimental and theoretical studies [3-11].

A complete mechanistic study of surface reactions requires the identification of the elementary processes, including the reaction intermediates. Hydrocarbon synthesis from carbon monoxide and hydrogen (synthesis gas which is often referred to as syngas) is probably the most important source for manufacturing fuels and chemicals from nonpetroleum-based sources [12]. Fischer-Tropsch synthesis (FTS) converts the syngas into high molecular weight 
hydrocarbons, which can subsequently be transformed into high-quality chemicals and ultraclean fuels [13, 14]. Various mechanisms have been proposed for the hydrocarbon chain initiation and growth steps [15]. One is the carbide mechanism, where $\mathrm{CO}$ dissociation precedes hydrogenation of the chemisorbed carbon atom to form $\mathrm{CH}_{\mathrm{x}}$ monomers that initiate the growth of hydrocarbon chains [16]. Hence, the dissociation of the surface-adsorbed CO molecule is an important step in the Fischer-Tropsch reaction [15].

Formyl (CHO) is also an important intermediate in hydrocarbon synthesis, FTS and hydrocarbon combustion $[17,18]$. In contrast to hydrocarbon synthesis, the catalytic combustion of hydrocarbons is a very important technology for efficient energy production [19]. The main reaction pathway of catalytic combustion of hydrocarbons is the reaction between methylidyne $(\mathrm{CH})$ and oxygen $(\mathrm{O})$ to form formyl (CHO) [20]. This $\mathrm{CHO}$ species subsequently decomposes to yield adsorbed carbon monoxide and hydrogen $(\mathrm{CHO} \rightarrow \mathrm{CO}+\mathrm{H})[18]$.

Gomes et al. [20] studied adsorption of the formyl species on $\mathrm{Cu}, \mathrm{Au}$ and $\mathrm{Pt}$ (111) surfaces using density functional theory (DFT) and where the metals are modelled as clusters. They found that the adsorption energy of formyl on the $\mathrm{Au}$ surface is very small $(-0.54 \mathrm{eV})$ and characteristic of a physisorbed species, whereas the interaction between $\mathrm{CHO}$ and the Pt surface is very strong (with an adsorption energy of $-2.61 \mathrm{eV}$ ). The calculated CHO adsorption energy on the $\mathrm{Cu}$ surface is approximately $-1.45 \mathrm{eV}$.

Inderwildi et al. [21] used DFT with the PW91 functional to study the mechanisms of hydrocarbon synthesis and combustion on noble metals. They suggested that $\mathrm{CHO}$ is an essential intermediate species in both synthesis and combustion reactions, and that these reactions have very similar mechanisms but in opposite directions, irrespective of the metal used to catalyze the reactions. Zhao et al. [22] also used DFT with the PW91 functional to explore the role of $\mathrm{CHO}$ in syngas conversion to hydrocarbons and its dependence on the $\mathrm{Co}$ and $\mathrm{Rh}$ catalyst surfaces. They found that the activation energy for insertion of $\mathrm{CHO}$ into $\mathrm{CH}_{x}(x=1-3)$ is the same, or even lower, than $\mathrm{CO}$ insertion or the formation of a $\mathrm{C}-\mathrm{C}$ bond by combining two $\mathrm{C}$ atoms. The mechanism of dry reforming of methane on a $\mathrm{Ni}$ catalyst was studied by Zhu et al. [23] using DFT with the PW91 functional. This reaction includes the formation and decomposition of $\mathrm{CHO}$. They showed that oxidation determines the overall reaction rates for both $\mathrm{C}$ and $\mathrm{CH}$ oxidation pathways.

Mahmood et al. [24] used DFT with the PW91 functional to study $\mathrm{CO}$ adsorption on several low and high Miller index surfaces of $\mathrm{Cu}$. They showed that the adsorption energy increases as the coordination number of the adsorption site decreases from 9 to 6 , in qualitative agreement with experimental observations. They also found a large decrease in the adsorption energy with increased surface coverage. The synthesis of formaldehyde and methanol from $\mathrm{CO}$ and $\mathrm{H}_{2}$ on a $\mathrm{Ni}(111)$ catalyst was investigated by Remediakis et al. [25] using DFT based on the RPBE functional. They showed that when CO and $\mathrm{H}$ are adsorbed on $\mathrm{Ni}(111)$ surfaces, $\mathrm{CO}$ hydrogenation is favoured over $\mathrm{CO}$ dissociation or desorption since it has the lowest activation energy. Further hydrogenation leads to the formation of formaldehyde $\left(\mathrm{CH}_{2} \mathrm{O}\right)$, methoxy $\left(\mathrm{CH}_{3} \mathrm{O}\right)$ and, finally, methanol $\left(\mathrm{CH}_{3} \mathrm{OH}\right)$.

Despite the developments in theoretical modelling combined with improved computer hardware, it is still computationally expensive to calculate reaction and activation energies of industrially relevant processes. It is therefore of interest to be able to predict relevant energies using, for example, descriptor-based approaches. The existence of linear relations between the adsorption, reaction and activation energies is the basis of many of these approaches [26]. For example, it was recently established that the activation energy varies linearly with the reaction energy for dissociative chemisorption of a number of molecules on a wide range of metal surfaces [27-29]. The Brønsted-Evans-Polanyi (BEP) relationship is an empirical observation that, for an elementary reaction, there is a linear relationship between the kinetics (activation barriers) and the thermodynamics (reaction energies). Similarly, the transition state scaling (TSS) relationship proposes a linear relation between the transition state energy and the initial (reactant) or final (product) state energy [30]. Fajin et al. [31] studied the generalized BEP relationships and descriptors for $\mathrm{O}-\mathrm{H}$ bond cleavage of organic molecules on transition metal surfaces. They found that there is a linear relationship between the $\mathrm{O}-\mathrm{H}$ bond breaking activation energy of $\mathrm{RO}-\mathrm{H}$ compounds ( $\mathrm{R}=$ organic moiety) on catalytic transition metal systems and the adsorption energy of the products. Consequently, the product's adsorption energy is a good descriptor for the activation barrier for the breaking $\mathrm{RO}-\mathrm{H}$ bond on transition metal surfaces. Pederson et al. [32] used DFT with the RPBE functional to study scaling properties of adsorption energies for hydrogen-containing molecules on transition metal surfaces. Their database provided a linear scaling relation connecting the adsorption energy of molecules such as $\mathrm{CH}_{x}$, $\mathrm{NH}_{x}, \mathrm{SH}_{x}$ and $\mathrm{OH}_{x}$ to the $\mathrm{C}, \mathrm{N}, \mathrm{S}$ and $\mathrm{O}$ adsorption energies, respectively, on transition metal surfaces. BEP relationships have also been validated for $\mathrm{C}-\mathrm{O}$ and $\mathrm{C}-\mathrm{C}$ bond dissociation during methanol decomposition and for ethylene dehydrogenation and hydrogenation on different Pd overlayer surfaces [33].

In this contribution, systematic and comparative DFT calculations have been performed to obtain the adsorption, reaction and activation energies of hydrocarbon synthesis

$$
\begin{aligned}
& \stackrel{1}{\mathrm{CO}} \rightarrow \mathrm{C}+\mathrm{O} \\
& 2 . \mathrm{CO}+\mathrm{H} \rightarrow \mathrm{CHO}
\end{aligned}
$$




$$
\stackrel{3}{\mathrm{C}} \mathrm{HO} \rightarrow \mathrm{CH}+\mathrm{O}
$$

on $\mathrm{Ag}, \mathrm{Au}, \mathrm{Al}, \mathrm{Cu}, \mathrm{Rh}, \mathrm{Pt}$ and $\mathrm{Pd}$ face-centred-cubic (111) surfaces. These surfaces were chosen because they have been used in numerous experimental and computational efforts [34-38]. The same methods were used to study hydrocarbon combustion on these surfaces. The splitting of $\mathrm{CH}(\mathrm{CH} \rightarrow \mathrm{C}+\mathrm{H})$ has been studied by us previously [39], and those data are complemented in the present contribution by studying the following two combustion reactions.

$$
\begin{aligned}
& \stackrel{4}{\mathrm{C}} \mathrm{H}+\mathrm{O} \rightarrow \mathrm{CHO} \\
& \stackrel{5}{\mathrm{C}} \mathrm{HO} \rightarrow \mathrm{CO}+\mathrm{H}
\end{aligned}
$$

The calculated energies are used to test the validity of the BEP and TSS relationships for these reactions on these metal surfaces. Since these relationships are seen to be valid for most of the reactions studied here, they are used to predict the energetics of these reactions on three new metal surfaces (Ni face-centred-cubic (111), Co hexagonal-closed-packed (111) and Fe body-centred-cubic (111) surfaces). The predicted values were compared to the same energies calculated from DFT, using the same models and methods that were used for the original surfaces. To the best of our knowledge this is the first time that the same models and methods are used for all of the above reactions and surfaces to investigate the mechanism of catalytic synthesis and combustion of hydrocarbons and to test the validity of the BEP and TSS relationships.

\section{Computational methods and models}

The Vienna ab initio simulation package (VASP) [40-45], using spin-polarized density functional theory, was used to obtain the results presented here. The exchange-correlation was treated within the generalized-gradient approximation (GGA) using the revised Perdew-Burke-Ernzerhof (RPBE) functional $[27,30,32,46,47]$. The interactions between valence electrons and ion cores were described using the projector-augmented wave method (PAW) [48-50]. The Kohn-Sham orbitals were expanded in a plane-wave basis set using a kinetic energy cut-off of $400 \mathrm{eV}$ [13], and a $4 \times 4 \times 1$ Monkhorst-Pack grid of $k$-points [51] was used for the numerical integration in reciprocal space. A $0.1 \mathrm{eV}$ Fermi smearing was used for the density of states calculations, and the convergence criteria for the geometry optimizations, which used a conjugate-gradient algorithm (CG), were $10^{-3} \mathrm{eV} \AA^{-1}$ for the forces acting on the ions and $10^{-5}$ $\mathrm{eV}$ for the total energy [23]. Also, a dense $41 \times 41 \times 1 k$-point grid was used for the density of state calculations.

The parameters used in this work have been used in previous, successful calculations of similar catalytic reactions
$[17,52,53]$. In addition, calculations made both here and in our previous work [39] confirm that the trends presented here are converged with respect to all important parameters, such as the size of the unit cell, the energy cut-off and the $k$-point mesh.

The metal (111) surfaces were constructed using a three-layer slab with a $2 \times 2$ unit cell and periodic boundary conditions in two directions (xy plane) to model a semi-infinite crystal surface. The ionic positions in the uppermost two layers and the adsorbates [54] were allowed to relax, while those in the bottom layer of the slab were fixed to maintain the crystal structure of the bulk. A $10-\AA$ vacuum region was placed between the slabs (in the $z$ direction) to ensure that the adsorbates do not interact with the neighbouring slab. Similar models have been used in previous studies of comparable systems [53].

The transition states were identified using the climbing image-nudged elastic band (CI-NEB) method [55, 56]. In this method, the lowest energy configurations of reactants and products were used as the initial and final states, and six images were created between these geometries using a linear interpolation [57]. A $-5.0-\mathrm{eV} \AA^{-2}$ spring force constant between images was used to relax all of the images until the maximum force acting on each ion was less than $0.1 \mathrm{eV} \AA^{-1}$.

The vibrational frequencies of the reactants, transition states and products were calculated using ionic displacements of $0.01 \AA$ and by diagonalizing the resulting Hessian matrix. Only the ionic positions of the adsorbates were displaced for these calculations. These frequencies were used to calculate the zero point vibrational energies (ZPVEs) and vibrational partition functions, as well as to confirm that the stationary structures were minimum energy structures (zero imaginary frequencies) or transition states (one imaginary frequency). The normal mode with the imaginary frequency was also analysed to ensure that this vibrational mode connected the reactants with the products.

The adsorption energies ( $\left.E_{\text {ads }}\right)$ of the reactants and products were calculated as $E_{\text {ads }}=E_{\text {(slab+adsorbate) }}$ $-\left(E_{\text {adsorbate }}+E_{\text {slab }}\right)$ where $E_{\text {(slab+adsorbate) }}$ is the total energy of the slab-adsorbate(s) system, $E_{\text {adsorbate }}$ is the total energy of the isolated geometry optimized adsorbate(s) in vacuum, and $E_{\text {slab }}$ is the total energy of the slab [58, 59]. All energies were ZPVE-corrected.

The rate constants $(k)$ were estimated from transition state theory [60] using

$k=\left(\frac{k_{\mathrm{B}} T}{h}\right)\left(\frac{q^{\#}}{q}\right) e^{\frac{-E_{\mathrm{a}}}{k_{\mathrm{B}} T}}$

where $k_{\mathrm{B}}$ is Boltzmann's constant, $T$ is the absolute temperature, $h$ is Planck's constant, and $E_{\mathrm{a}}$ is the ZPVE-corrected 
activation energy. $q$ and $q^{\#}$ are the partition functions for the reactants and transition state, respectively. The partition functions were calculated assuming harmonic vibrations.

There are four high symmetry adsorption sites on all surfaces studied here (shown in Panel a of Fig. 1) except Fe (111) (shown in Panel b of Fig. 1). The hcp hollow site (where the central metal atom is in the second surface layer) is labelled A, the top site is above the uppermost metal surface atom and is labelled $\mathrm{B}$, the bridge site between two neighbouring atoms is labelled $\mathrm{C}$, and the fcc hollow site (where the central atom is in the third surface layer) is labelled $\mathrm{D}$. There are five high symmetry adsorption sites on the Fe (111) surface. These are the top site labelled B, a short bridge site labelled $\mathrm{E}$, a long bridge site labelled $\mathrm{F}$, a pseudo-threefold hollow site labelled $\mathrm{G}$ and rectangular fourfold hollow site labelled $\mathrm{H}$.

Geometry optimizations were performed by placing the adsorbate, with different initial orientations, on each of the adsorption sites shown in Fig. 1 and subsequently optimizing the system to yield the lowest ZPVE-corrected energy structure. The site that yielded the lowest energy was the preferred adsorption site. The preferred sites, energies and geometries of co-adsorbed adsorbates were obtained by placing the adsorbates in the same periodic cell and in their lowest energy sites identified from the geometry optimisations of the individual adsorbates [52]. The reaction energies $(\Delta E)$ are the difference between product (final state) and reactant (initial state) energies $\left(\Delta E=E_{\mathrm{FS}}-E_{\mathrm{IS}}\right)$, and the activation energies $\left(E_{\mathrm{a}}\right)$ are the difference between transition state and initial state energies $\left(E_{\mathrm{a}}=E_{\mathrm{TS}}-E_{\mathrm{IS}}\right)$.

\section{Results and discussion}

\subsection{Adsorption energies of reactants and products}

The ZPVE-corrected adsorption energies, $E_{\mathrm{ads}}$, for $\mathrm{CH}, \mathrm{C}$ and $\mathrm{H}$ have been previously calculated by us using the same

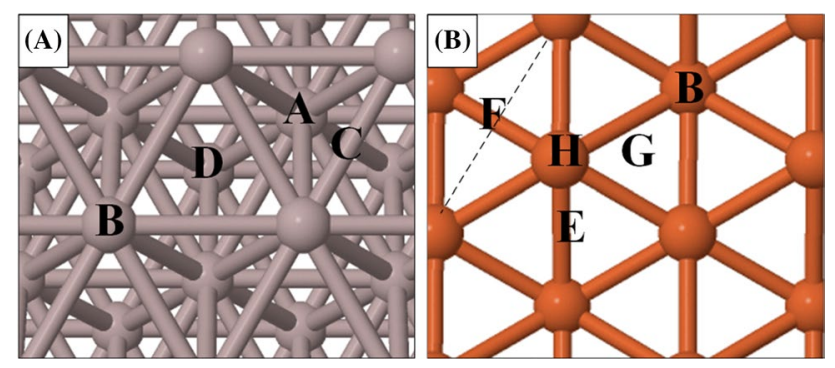

Fig. 1 Adsorption sites on the a $\mathrm{Ag}, \mathrm{Au}, \mathrm{Al}, \mathrm{Cu}, \mathrm{Rh}, \mathrm{Pt}, \mathrm{Pd}, \mathrm{Ni}$ and Co (111) surfaces and b Fe (111) surface. A is an hcp site; B is a top site; $\mathrm{C}$ is a bridge site; $\mathrm{D}$ is a fcc site; $\mathrm{E}$ is a short bridge site; $\mathrm{F}$ is a long bridge site; $\mathrm{G}$ is a pseudo-threefold hollow site, and $\mathrm{H}$ is a rectangular fourfold hollow site methods and models that are used in the present study [39]. $E_{\text {ads }}$, for the remaining species involved in the hydrocarbon synthesis and combustion reactions studied here, are presented in Table 1 . Previously obtained computed and experimental data are shown for the sake of comparison. Details of the adsorption sites and geometries of the reactants, transition states and products are given in Tables S1-S3 in the supporting information.

The calculated $\mathrm{CHO}$ adsorption energies on these surfaces decrease in the order $\mathrm{Ag}>\mathrm{Cu}>\mathrm{Au}>\mathrm{Al}>\mathrm{Pd}>$ $\mathrm{Rh}>\mathrm{Pt}$. The highest adsorption energy (weakest adsorption) is on the $\mathrm{Ag}(111)$ surface and is $-0.52 \mathrm{eV}$, compared to $-2.14 \mathrm{eV}$ on $\mathrm{Pt}$ (111). The preferred adsorption site for $\mathrm{CHO}$ is the top site for all surfaces except for $\mathrm{Al}, \mathrm{Rh}$ and $\mathrm{Pd}$ where it is the fcc site for $\mathrm{Al}$ and bridge site for $\mathrm{Rh}$ and $\mathrm{Pd}$. Similar trends in adsorption energies are reported in previous studies. For example, the $\mathrm{CHO}$ adsorption energies in the study by Lin et al. [35] decrease in the order $\mathrm{Cu}>\mathrm{Au}$ $>\mathrm{Ag}>\mathrm{Pd}>\mathrm{Rh}>\mathrm{Pt}$, which, except for $\mathrm{Ag}$, is in agreement with the trend seen in the present work. They found lower adsorption energies for $\mathrm{CHO}$ on all surfaces, and this difference is probably due to the fact that they used different super cell size, adsorption sites and exchange-correlation functional.

The calculated adsorption energies for $\mathrm{CO}$ vary from $0.16 \mathrm{eV}$ on $\mathrm{Au}(111)$ to $-1.50 \mathrm{eV}$ on $\mathrm{Pt}(111)$ and decrease (become more negative) in the order $\mathrm{Au}>\mathrm{Ag}>\mathrm{Al}>\mathrm{Cu}$ $>\mathrm{Rh}>\mathrm{Pd}>\mathrm{Pt}$. The most stable adsorption site for $\mathrm{CO}$ is the fcc site for all surfaces except for $\mathrm{Ag}, \mathrm{Au}$ and $\mathrm{Al}$, where it is the top site for $\mathrm{Ag}$ and $\mathrm{Al}$ and the bridge site for $\mathrm{Au}$. The trends in the calculated energies of $\mathrm{CO}$ adsorption are similar to those seen in previous studies. For example, the $\mathrm{CO}$ adsorption energies obtained by Hammer et al. [7] decreased in the order $\mathrm{Ag}>\mathrm{Au}>\mathrm{Al}>\mathrm{Cu}>\mathrm{Pd}>\mathrm{Pt}$, which is similar to the trend seen in the present work.

The calculated $\mathrm{O}$ adsorption energies decrease in the order $\mathrm{Au}>\mathrm{Ag}>\mathrm{Pt}>\mathrm{Pd}>\mathrm{Cu}>\mathrm{Rh}>\mathrm{Al}$. The weakest adsorption is $-2.40 \mathrm{eV}$ on the $\mathrm{Au}$ (111) surface compared to $-6.79 \mathrm{eV}$ on the $\mathrm{Al}$ (111) surface. The preferred adsorption site for atomic oxygen is the fcc site for all surfaces. The $\mathrm{O}$ adsorption energies in a previous study by Liao et al. follow the same trend as that discussed in the present work ( $\mathrm{Au}$ $>\mathrm{Ag}>\mathrm{Pd}>\mathrm{Pt}>\mathrm{Cu}>\mathrm{Rh}$ ) except for $\mathrm{Pd}$ and $\mathrm{Pt}$, which are very similar in the present study $(-3.68 \mathrm{eV}$ on Pt and $-3.69 \mathrm{eV}$ on $\mathrm{Pd}$ ). The atomic oxygen adsorption energies reported by Liao et al. are more negative than those reported in this study, and the difference is probably due to the fact that they used different super cell size, adsorption sites and exchange-correlation functional.

The calculated $(\mathrm{C}+\mathrm{O})$ co-adsorption energies decrease in the order $\mathrm{Ag}>\mathrm{Au}>\mathrm{Cu}>\mathrm{Pt}>\mathrm{Pd}>\mathrm{Rh}>\mathrm{Al}$. The weakest adsorption is $-4.99 \mathrm{eV}$ on the $\mathrm{Ag}$ (111) surface compared to $-11.99 \mathrm{eV}$ on the $\mathrm{Al}$ (111). Co-adsorption 
Table 1 ZPVE-corrected adsorption and co-adsorption energies $(\mathrm{eV})$ of all species involved in the hydrocarbon synthesis and combustion reactions. The references for the previously published data are given in the footnote to the table

\begin{tabular}{|c|c|c|c|c|c|c|}
\hline Surface & $\mathrm{CHO}$ & $\mathrm{CO}$ & $\mathrm{O}$ & $\mathrm{C}+\mathrm{O}$ & $\mathrm{CO}+\mathrm{H}$ & $\mathrm{CH}+\mathrm{O}$ \\
\hline \multicolumn{7}{|l|}{$\mathrm{Ag}$} \\
\hline Current work & -0.52 & -0.01 & -2.83 & -4.99 & -1.55 & -5.28 \\
\hline Previous studies & $-1.08^{b}$ & $0.09^{j}$ & $-3.60^{\mathrm{a}}$ & - & - & - \\
\hline \multicolumn{7}{|l|}{$\mathrm{Au}$} \\
\hline Current work & -0.94 & 0.16 & -2.40 & -5.91 & -1.62 & -6.06 \\
\hline Previous studies & $-1.51^{\mathrm{b}},-0.54^{\mathrm{i}}$ & $-0.04^{j}$ & $-3.12^{\mathrm{a}}$ & - & - & - \\
\hline \multicolumn{7}{|l|}{$\mathrm{Al}$} \\
\hline Current work & -1.70 & -0.14 & -6.79 & -11.99 & -1.86 & -12.32 \\
\hline Previous studies & - & $-0.49^{j}$ & - & - & - & - \\
\hline \multicolumn{7}{|l|}{$\mathrm{Cu}$} \\
\hline Current work & -0.84 & -0.36 & -4.07 & -7.26 & -2.46 & -7.54 \\
\hline Previous studies & $-1.43^{\mathrm{b}},-1.45^{\mathrm{i}}$ & $\begin{array}{l}-1.30^{\mathrm{c}},-0.49^{\mathrm{d}}, \\
\quad-0.62^{\mathrm{g}}, \\
-0.62^{\mathrm{j}}\end{array}$ & $-5.07^{\mathrm{a}},-4.34^{\mathrm{k}}$ & - & - & - \\
\hline \multicolumn{7}{|l|}{$\mathrm{Rh}$} \\
\hline Current work & -1.89 & -1.36 & -4.41 & -10.43 & -3.74 & -10.14 \\
\hline Previous studies & $-2.44^{\mathrm{b}}$ & $-1.67^{\mathrm{g}}$ & $-6.67^{\mathrm{a}}$ & - & - & - \\
\hline \multicolumn{7}{|l|}{$\mathrm{Pt}$} \\
\hline Current work & -2.14 & -1.50 & -3.68 & -9.01 & -3.86 & -8.99 \\
\hline Previous studies & $-2.61^{\mathrm{b}},-2.61^{\mathrm{i}}$ & $-1.56^{\mathrm{g}},-1.45^{\mathrm{j}}$ & $-4.24^{\mathrm{a}}$ & & & \\
\hline \multicolumn{7}{|l|}{$\mathrm{Pd}$} \\
\hline Current work & -1.78 & -1.48 & -3.69 & -9.20 & -3.84 & -8.67 \\
\hline Previous studies & $-2.32^{\mathrm{b}}$ & $\begin{array}{l}-1.96^{\mathrm{e}},-1.56^{\mathrm{f}} \\
-1.60^{\mathrm{g}} \\
-1.65^{\mathrm{h}} \\
-1.30^{\mathrm{j}}\end{array}$ & $\begin{array}{l}-3.98^{\mathrm{e}},-3.49^{\mathrm{f}} \\
-4.09^{\mathrm{a}}\end{array}$ & - & - & - \\
\hline
\end{tabular}

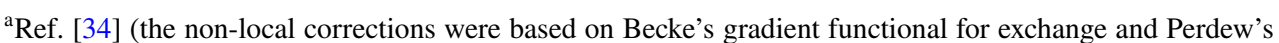
gradient functional for correlation, using a two-layer slab)

${ }^{\mathrm{b}}$ Ref. [35] (GGA-PW91 calculations using a $4 \times 4$ unit cell and five-layer slab)

${ }^{c}$ Ref. [36] (GGA-PW91 calculations using a $3 \times 3$ unit cell and five-layer slab)

${ }^{\mathrm{d}}$ Ref. [37] (experimental data from thermal desorption spectroscopy)

${ }^{\mathrm{e}}$ Ref. [61] (GGA-PBE calculations using a $2 \times 2$ unit cell and three-layer slab)

${ }^{\mathrm{f}}$ Ref [61] (GGA-RPBE calculations using a $2 \times 2$ unit cell and three-layer slab)

${ }^{\mathrm{g}}$ Ref. [62] (GGA-PBE calculations using a $2 \times 4$ unit cell and five-layer slab)

${ }^{\mathrm{h}}$ Ref. [47] (GGA-RPBE calculations using a $2 \times 2$ unit cell and three-layer slab)

${ }^{\mathrm{i}}$ Ref. [20] (DFT-B3LYP calculations using a $2 \times 2$ unit cell and three-layer slab)

${ }^{j}$ Ref. [7] (GGA-RPBE calculations using a $2 \times 2$ unit cell and three-layer slab)

${ }^{\mathrm{k}}$ Ref. [63] (GGA-RPBE calculations using a $2 \times 2$ unit cell and three-layer slab) data for these species, as well as those discussed below, have not been reported previously, and hence comparison with other studies is not possible.

For $(\mathrm{CO}+\mathrm{H})$ co-adsorption on these surfaces, $E_{\text {ads }}$ range from $-1.55 \mathrm{eV}$ on $\mathrm{Ag}(111)$ to $-3.86 \mathrm{eV}$ on $\mathrm{Pt}$ (111) and decrease in the order $\mathrm{Ag}>\mathrm{Au}>\mathrm{Al}>\mathrm{Cu}>\mathrm{R}$ $\mathrm{h}>\mathrm{Pd}>\mathrm{Pt}$. The co-adsorption energy is therefore highest on the $\mathrm{Ag}$ (111) surface, which was also seen for the $\mathrm{CH}$, $\mathrm{C}$ and $\mathrm{H}$ adsorbates.

The calculated $(\mathrm{CH}+\mathrm{O})$ co-adsorption energies range from $-5.28 \mathrm{eV}$ on the $\mathrm{Ag}$ (111) surface to $-12.32 \mathrm{eV}$ on the $\mathrm{Al}(111)$ and decrease in the order $\mathrm{Ag}>\mathrm{Au}>\mathrm{Cu}>$ $\mathrm{Pd}>\mathrm{Pt}>\mathrm{Rh}>\mathrm{Al}$. 
The weakest adsorption is on the $\mathrm{Ag}$ (111) surface for all species, except for the $\mathrm{CO}$ and $\mathrm{O}$ species, where it is on the $\mathrm{Au}$ (111) surface. In contrast, the strongest adsorption is on the $\mathrm{Pt}$ (111) surface for all species except for the $\mathrm{CH}$, $\mathrm{O}, \mathrm{C}+\mathrm{O}$ and $\mathrm{CH}+\mathrm{O}$ species, where it is on the $\mathrm{Rh}(111)$ for the $\mathrm{CH}$ species and on the $\mathrm{Al}(111)$ for the $\mathrm{O}, \mathrm{C}+\mathrm{O}$ and $\mathrm{CH}+\mathrm{O}$ species. Co-adsorption data for the products of $\mathrm{CO}$ and $\mathrm{CHO}$ splitting have not been reported previously, and hence, comparison with other studies is not possible.

\section{Reaction and activation energies}

\subsection{Catalytic hydrocarbon synthesis}

The reaction energies, activation barriers and rate constants at $600 \mathrm{~K}$, which is typical for industrial low-temperature catalytic reactions of hydrocarbons [64-66], for hydrocarbon synthesis are shown in Table 2.

The results in Table 2 show that the reaction energies for dissociation of $\mathrm{CO}$ decrease in the order $\mathrm{Ag}>\mathrm{Au}>\mathrm{Cu}>$ $\mathrm{Pt}>\mathrm{Pd}>\mathrm{Rh}>\mathrm{Al}$. The reaction is endothermic on all surfaces except for the $\mathrm{Al}$ (111) surface, where it is exothermic with a reaction energy $-0.87 \mathrm{eV}$.

The calculated activation energies for dissociation of $\mathrm{CO}$ decrease in the order $\mathrm{Ag}>\mathrm{Au}>\mathrm{Pd}>\mathrm{Cu}>\mathrm{Rh}>\mathrm{Pt}>\mathrm{A}$ 1 , which is similar to the order for the reaction energies. The highest activation energy for $\mathrm{CO}$ splitting, obtained on the $\mathrm{Ag}$ (111) surface, was $6.05 \mathrm{eV}$, compared to $2.01 \mathrm{eV}$ on $\mathrm{Al}$ (111).

The reaction rate constants for the $\mathrm{CO}$ dissociation are strongly influenced by the different metal surfaces, and at $600 \mathrm{~K}$, they decrease from $1.93 \times 10^{6} \mathrm{~s}^{-1}$ on $\mathrm{Al}(111)$ to $1.99 \times 10^{-39} \mathrm{~s}^{-1}$ on $\mathrm{Ag}(111)$. Thus, $\mathrm{Al}$ is the most active catalyst for $\mathrm{CO}$ splitting at $600 \mathrm{~K}$. The trend in rate constants follows the opposite trend to the activation energies, with a higher activation energy leading to a lower rate constant.

The reaction energies for $\mathrm{CO}$ hydrogenation decrease in the order $\mathrm{Pd}>\mathrm{Rh}>\mathrm{Pt}>\mathrm{Cu}>\mathrm{Ag}>\mathrm{Au}>\mathrm{Al}$. The reaction on the $\mathrm{Ag}, \mathrm{Cu}, \mathrm{Rh}, \mathrm{Pt}$ and $\mathrm{Pd}$ (111) surfaces is endothermic, while it is exothermic on the $\mathrm{Au}$ and $\mathrm{Al}(111)$ surfaces with reaction energies of $-0.21 \mathrm{eV}$ and $-0.74 \mathrm{eV}$, respectively.

The activation energy for this reaction ranges from $1.32 \mathrm{eV}$ on $\mathrm{Rh}$ (111) to $0.29 \mathrm{eV}$ on $\mathrm{Al}$ (111) and decreases in the order $\mathrm{Rh}>\mathrm{Pd}>\mathrm{Pt}>\mathrm{Cu}>\mathrm{Au}>\mathrm{Ag}>\mathrm{Al}$. The calculated reaction rate constants decrease in the opposite order to the activation energies. Thus, $\mathrm{Rh}$ and $\mathrm{Pd}$ are the least active catalysts and $\mathrm{Al}(111)$ is the most active catalyst for $\mathrm{CO}$ hydrogenation at $600 \mathrm{~K}$.

The reaction energy of formyl dissociation to $\mathrm{CH}$ and $\mathrm{O}$ decreases in the order of $\mathrm{Ag}>\mathrm{Au}>\mathrm{Cu}>\mathrm{Pd}>\mathrm{Pt}>$ $\mathrm{Rh}>\mathrm{Al}$. This reaction follows the same order as CO dissociation, except for Pd and Pt. The reaction is endothermic on all surfaces except for the $\mathrm{Al}$ (111) surface, where it is exothermic with a reaction energy of $-2.12 \mathrm{eV}$.

The calculated activation energies for dissociation of $\mathrm{CHO}$ to $\mathrm{CH}$ and $\mathrm{O}$ decrease in the order $\mathrm{Au}>\mathrm{Ag}>\mathrm{P}$ $\mathrm{t}>\mathrm{Pd}>\mathrm{Cu}>\mathrm{Rh}>\mathrm{Al}$. The highest activation energy obtained on the $\mathrm{Au}$ (111) surface was $3.88 \mathrm{eV}$, compared to $0.42 \mathrm{eV}$ on $\mathrm{Al}$ (111). The reaction rate constant ranges from $9.46 \times 10^{8} \mathrm{~s}^{-1}$ on $\mathrm{Al}(111)$ to $4.07 \times 10^{-22} \mathrm{~s}^{-1}$ on $\mathrm{Au}$ (111). Similarly to the two reactions discussed above, the trend in rate constants follows the opposite trend to the activation energies, with a higher activation energy leading to a lower rate constant. $\mathrm{Al}(111)$ is the most active catalyst for dissociation of $\mathrm{CHO}$ to $\mathrm{CH}$ and $\mathrm{O}$.

For all three reactions studied here, the lowest reaction energy is on the $\mathrm{Al}$ (111) surface and the highest reaction energy is on $\mathrm{Ag}$ (111), except for the $\mathrm{CO}$ hydrogenation where it is on $\mathrm{Pd}$ (111). The trends of the reaction energies for the $\mathrm{CO} \rightarrow \mathrm{C}+\mathrm{O}$ and $\mathrm{CHO} \rightarrow \mathrm{CH}+\mathrm{O}$ reactions are the same except for Pd and Pt. The smallest activation energy, and consequently the highest reaction rate constant, is on $\mathrm{Al}$ (111) surface for all synthesis reactions. $\mathrm{Al}$ (111) is therefore the most active catalyst for all three reactions.

Figure 2 shows the geometries of the reactants, transition states and products of the species that are discussed with
Table 2 Reaction and activation energies $(\mathrm{eV})$ and reaction rate constants at $600 \mathrm{~K}\left(\mathrm{~s}^{-1}\right)$ for the hydrocarbon synthesis reactions. The energies are ZPVE-corrected. Reaction and activation energies for these reactions have not previously been reported

\begin{tabular}{|c|c|c|c|c|c|c|c|c|c|}
\hline \multicolumn{10}{|c|}{ Catalytic hydrocarbon synthesis } \\
\hline \multirow[t]{2}{*}{ Surface } & \multicolumn{3}{|c|}{$\mathrm{CO} \rightarrow \mathrm{C}+\mathrm{O}$} & \multicolumn{3}{|c|}{$\mathrm{CO}+\mathrm{H} \rightarrow \mathrm{CHO}$} & \multicolumn{3}{|c|}{$\mathrm{CHO} \rightarrow \mathrm{CH}+\mathrm{O}$} \\
\hline & $\Delta E$ & $E_{\mathrm{a}}$ & $k$ & $\Delta E$ & $E_{\mathrm{a}}$ & $k$ & $\Delta E$ & $E_{\mathrm{a}}$ & $k$ \\
\hline $\mathrm{Ag}$ & 5.98 & 6.05 & $1.99 \times 10^{-39}$ & 0.13 & 0.53 & $1.09 \times 10^{9}$ & 3.73 & 3.77 & $9.61 \times 10^{-21}$ \\
\hline $\mathrm{Au}$ & 5.03 & 5.05 & $4.43 \times 10^{-31}$ & -0.21 & 0.64 & $1.12 \times 10^{8}$ & 3.37 & 3.88 & $4.07 \times 10^{-22}$ \\
\hline $\mathrm{Al}$ & -0.87 & 2.01 & $1.93 \times 10^{6}$ & -0.74 & 0.29 & $1.1 \times 10^{9}$ & -2.12 & 0.42 & $9.46 \times 10^{8}$ \\
\hline $\mathrm{Cu}$ & 4.08 & 4.10 & $2.89 \times 10^{-23}$ & 0.72 & 0.85 & $7.90 \times 10^{5}$ & 1.80 & 2.03 & $7.95 \times 10^{-8}$ \\
\hline $\mathrm{Rh}$ & 1.90 & 3.97 & $6.80 \times 10^{-22}$ & 0.95 & 1.32 & $1.85 \times 10^{2}$ & 0.24 & 1.61 & $7.32 \times 10^{-2}$ \\
\hline $\mathrm{Pt}$ & 3.46 & 3.3 & $2.50 \times 10^{-16}$ & 0.83 & 1.11 & $3.40 \times 10^{3}$ & 1.50 & 2.49 & $7.96 \times 10^{-10}$ \\
\hline $\mathrm{Pd}$ & 3.25 & 4.31 & $1.64 \times 10^{-24}$ & 1.16 & 1.31 & $3.92 \times 10^{2}$ & 1.61 & 2.4 & $1.62 \times 10^{-8}$ \\
\hline
\end{tabular}



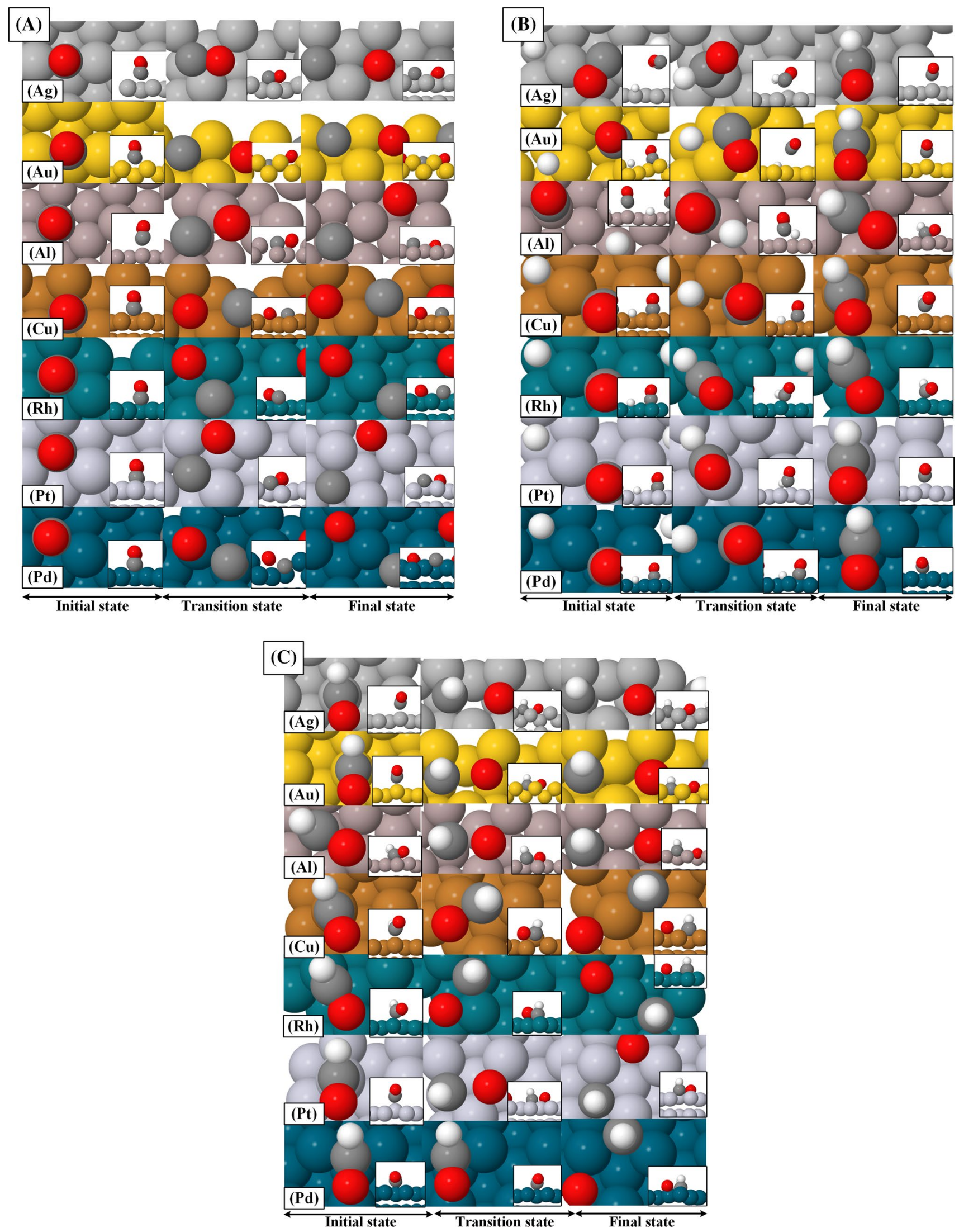

Fig. 2 Top and side views of the optimized structures for the initial, transition and final states for the $\mathbf{a} \mathrm{CO} \rightarrow \mathrm{C}+\mathrm{O}, \mathbf{b} \mathrm{CO}+\mathrm{H} \rightarrow \mathrm{CHO}$ and $\mathbf{c}$ $\mathrm{CHO} \rightarrow \mathrm{CH}+\mathrm{O}$ reactions 
reference to Table 2. Data for the $\mathrm{CH} \rightarrow \mathrm{C}+\mathrm{H}$ reaction is not shown here since it has been presented elsewhere [39].

\subsubsection{Catalytic hydrocarbon combustion}

The reaction and activation energies for the hydrocarbon combustion reactions studied here, as well as the reaction rate constants at $600 \mathrm{~K}$, are listed in Table 3 together with results of previous studies when available.

The reaction energies for $\mathrm{CHO}$ dissociation to $\mathrm{CO}$ and $\mathrm{H}$ decrease in the order $\mathrm{Al}>\mathrm{Au}>\mathrm{Ag}>\mathrm{Cu}>\mathrm{Pt}>\mathrm{Rh}>\mathrm{P}$ $\mathrm{d}$. The highest reaction energy, obtained on the $\mathrm{Al}$ (111) surface, was $0.64 \mathrm{eV}$, compared to $-1.16 \mathrm{eV}$ on $\mathrm{Pd}(111)$. The reaction on the $\mathrm{Ag}, \mathrm{Cu}, \mathrm{Rh}, \mathrm{Pt}$ and $\mathrm{Pd}$ (111) is exothermic, while it is endothermic on the Au and Al (111) surfaces. Similar reaction energies are reported in the previous studies by Inderwildi et al. [21]. They found exothermic reaction energies on the $\mathrm{Rh}$ (111), Pt (111) and Pd (111) surfaces of $-1.33 \mathrm{eV},-0.89 \mathrm{eV}$ and $-1.16 \mathrm{eV}$ compared to $-0.95 \mathrm{eV}$, $-0.89 \mathrm{eV}$ and $-1.16 \mathrm{eV}$ obtained here, respectively.

The activation energy for this reaction decreases in the order $\mathrm{Al}>\mathrm{Au}>\mathrm{Ag}>\mathrm{Rh}>\mathrm{Pt}>\mathrm{Pd}>\mathrm{Cu}$. It ranges from $0.93 \mathrm{eV}$ on the $\mathrm{Al}$ (111) surface to $0.13 \mathrm{eV}$ on the $\mathrm{Cu}$ (111) surface. The calculated activation energies are comparable with most of the previous results. Inderwildi et al. [21] reported activation energies of $0.30,0.57$ and $0.36 \mathrm{eV}$ for the Rh, Pt and Pd (111) surfaces, respectively, compared to $0.37,0.28$ and $0.14 \mathrm{eV}$ in this work. As discussed above, these differences may be due to difference in the functionals and system sizes used in the studies.
The reaction rate constants at $600 \mathrm{~K}$ decrease from $3.02 \times 10^{12} \mathrm{~s}^{-1}$ on $\mathrm{Pd}(111)$ to $1.03 \times 10^{5} \mathrm{~s}^{-1}$ on $\mathrm{Al}(111)$ and decrease in the order $\mathrm{Pd}>\mathrm{Ag}>\mathrm{Rh}>\mathrm{Pt}>\mathrm{Cu}>\mathrm{Au}>\mathrm{A}$ 1. $\mathrm{Pd}(111)$ is the most active catalyst for $\mathrm{CHO}$ dissociation.

The results in Table 3 show that the reaction energies for oxidation of $\mathrm{CH}$ decrease in the order $\mathrm{Al}>\mathrm{Rh}>\mathrm{Pt}>$ $\mathrm{Pd}>\mathrm{Cu}>\mathrm{Au}>\mathrm{Ag}$. The lowest reaction energy for $\mathrm{CH}$ oxidation, obtained on the $\mathrm{Ag}$ (111) surface, was $-3.73 \mathrm{eV}$, compared to $2.12 \mathrm{eV}$ on $\mathrm{Al}$ (111). This reaction is exothermic on the all surfaces except for $\mathrm{Al}$, where it is endothermic. Inderwildi et al. [21] obtained reaction energies of $-0.14 \mathrm{eV},-1.18 \mathrm{eV}$ and $-1.38 \mathrm{eV}$ on the $\mathrm{Rh}(111), \mathrm{Pt}$ (111) and Pd (111) surfaces, respectively, which are similar to the values obtained in this work of $-0.24 \mathrm{eV},-1.50 \mathrm{eV}$ and $-1.61 \mathrm{eV}$. As discussed above, these differences may be due to differences in the system sizes and functionals used in the studies.

The calculated activation energies for $\mathrm{CH}$ oxidation decrease in the order $\mathrm{Al}>\mathrm{Rh}>\mathrm{Pt}>\mathrm{Pd}>\mathrm{Au}>\mathrm{Cu}>\mathrm{A}$ g. The highest activation energy for $\mathrm{CH}$ oxidation, obtained on the $\mathrm{Al}$ (111) surface, was $2.53 \mathrm{eV}$, compared to $0.04 \mathrm{eV}$ on Ag (111) surface. The results presented here are in agreement with those obtained previously. For example, Inderwildi et al. [21] reported activation energies of $1.15,1.12$ and $0.78 \mathrm{eV}$ for the Rh, Pt and Pd (111) surfaces, respectively. These can be compared to $1.37,0.98$ and $0.79 \mathrm{eV}$ obtained in this work. Some activation energies reported by Inderwildi et al. are higher than those reported in this study, and the difference is probably due to the fact that they used different super cell size, adsorption sites and exchange-correlation functional.
Table 3 Reaction and activation energies $(\mathrm{eV})$ and reaction rate constants at $600 \mathrm{~K}\left(\mathrm{~s}^{-1}\right)$ for the hydrocarbon combustion reactions. The energies are ZPVE-corrected

\begin{tabular}{|c|c|c|c|c|c|c|c|}
\hline \multicolumn{8}{|c|}{ Catalytic hydrocarbon combustion } \\
\hline \multirow[t]{2}{*}{ Surface } & & \multicolumn{3}{|c|}{$\mathrm{CHO} \rightarrow \mathrm{CO}+\mathrm{H}$} & \multicolumn{3}{|c|}{$\mathrm{CH}+\mathrm{O} \rightarrow \mathrm{CHO}$} \\
\hline & & $\Delta E$ & $E_{\mathrm{a}}$ & $k$ & $\Delta E$ & $E_{\mathrm{a}}$ & $k$ \\
\hline \multirow[t]{2}{*}{$\mathrm{Ag}$} & Current work & -0.13 & 0.53 & $4.34 \times 10^{10}$ & -3.73 & 0.04 & $3.83 \times 10^{12}$ \\
\hline & Previous studies & - & - & - & - & - & - \\
\hline \multirow[t]{2}{*}{$\mathrm{Au}$} & Current work & 0.21 & 0.84 & $6.15 \times 10^{5}$ & -3.37 & 0.51 & $5.60 \times 10^{8}$ \\
\hline & Previous studies & - & - & - & - & - & - \\
\hline \multirow[t]{2}{*}{$\mathrm{Al}$} & Current work & 0.64 & 0.93 & $1.03 \times 10^{5}$ & 2.12 & 2.53 & $4.17 \times 10^{-9}$ \\
\hline & Previous studies & - & - & - & - & - & - \\
\hline \multirow[t]{2}{*}{$\mathrm{Cu}$} & Current work & -0.72 & 0.13 & $8.28 \times 10^{9}$ & -1.80 & 0.24 & $1.11 \times 10^{11}$ \\
\hline & Previous studies & - & - & - & - & - & - \\
\hline \multirow[t]{2}{*}{$\mathrm{Rh}$} & Current work & -0.95 & 0.37 & $3.35 \times 10^{10}$ & -0.24 & 1.37 & $3.89 \times 10^{1}$ \\
\hline & Previous studies & $-1.33^{\mathrm{a}}$ & $0.30^{\mathrm{a}}$ & - & $-0.14^{\mathrm{a}}$ & $1.15^{\mathrm{a}}$ & - \\
\hline \multirow[t]{2}{*}{$\mathrm{Pt}$} & Current work & -0.83 & 0.28 & $9.01 \times 10^{9}$ & -1.50 & 0.98 & $1.04 \times 10^{5}$ \\
\hline & Previous studies & $-0.89^{\mathrm{a}}$ & $0.57^{\mathrm{a}}$ & & $-1.18^{\mathrm{a}}$ & $1.12^{\mathrm{a}}$ & - \\
\hline \multirow[t]{2}{*}{$\mathrm{Pd}$} & Current work & -1.16 & 0.14 & $3.02 \times 10^{12}$ & -1.61 & 0.79 & $2.62 \times 10^{6}$ \\
\hline & Previous studies & $-1.16^{\mathrm{a}}$ & $0.36^{\mathrm{a}}$ & - & $-1.38^{\mathrm{a}}$ & $0.78^{\mathrm{a}}$ & - \\
\hline
\end{tabular}

${ }^{a}$ Ref. [21] (GGA-PBE calculations using a $2 \times 2$ unit cell and three-layer slab) 
The reaction rate constant at $600 \mathrm{~K}$ ranges from $3.83 \times 10^{12} \mathrm{~s}^{-1}$ on $\mathrm{Ag}(111)$ to $4.17 \times 10^{-9}$ on $\mathrm{Al}(111)$ and decreases in the order $\mathrm{Ag}>\mathrm{Cu}>\mathrm{Au}>\mathrm{Pd}>\mathrm{Pt}>\mathrm{Rh}>\mathrm{Al}$. The trend in rate constants follows the opposite trend to the activation energies, with a higher activation energy leading to a lower rate constant. $\mathrm{Ag}$ (111) is the most active catalyst for $\mathrm{CH}$ oxidation.

The highest reaction energy is obtained on the Al (111) surface for both combustion reactions. As for the synthesis reactions discussed before, the trend in rate constants for the combustion reactions follows the opposite trend to the activation energies, with a higher activation energy leading to a lower rate constant, except for $\mathrm{CHO} \rightarrow \mathrm{CO}+\mathrm{H}$ reaction.

\subsection{Brønsted-Evans-Polanyi (BEP) and transition state scaling (TSS) relationships}

According to the BEP relationship, the activation energy of a chemical reaction is linearly proportional to its reaction energy [67], and according to the TSS relationship the transition state energy is linearly proportional to the final state or initial state energy. Figure 3 shows these correlations for the hydrocarbon synthesis and combustion reactions on the metal surfaces listed in Tables 1, 2, 3. This figure reveals that the synthesis reactions support the BEP relationship with $R^{2}$ values of $0.83,0.88$ and 0.94 for $\mathrm{CO}$ dissociation, $\mathrm{CO}$ hydrogenation and formyl dissociation to $\mathrm{CH}+\mathrm{O}$, respectively. The BEP relationships are also valid for the combustion reactions. The activation energies for $\mathrm{CH}$ oxidation and formyl dissociation to $\mathrm{CO}+\mathrm{H}$ are linearly proportional to the reaction energies with $R^{2}$ values of 0.89 and 0.88 , respectively. As shown previously [39], the activation energy for the $\mathrm{CH}$ splitting combustion reaction is linearly proportional to the reaction energy with and $R^{2}$ of 0.94 .

The TSS relationship is excellent with an $R^{2}$ value of 1 for all synthesis and combustion reactions.

The validity of the BEP and TSS relationships was also tested by using the equations shown in Fig. 3 to predict the activation energies from the reaction energies (BEP) and the transition state energies from the initial state energies (TSS) for three new metal surfaces. These were the Ni (facecentred-cubic (111)), Co (hexagonal-closed-packed (111)) and $\mathrm{Fe}$ (body-centred-cubic (111)) surfaces. The predictions were for all synthesis and combustion reactions studied here. The predicted values were subsequently compared with the values calculated using the methods and models described in Sect. 2. The DFT data are shown in Tables S1-S3 in the supporting information, and the initial, transition and final state structures are illustrated in Fig. 4.

The activation and transition state energies predicted by the BEP and TSS relationships, as well as those determined from DFT calculations, are shown in Table 4. It can be seen that the activation energies predicted by the
$\mathrm{BEP}$ relationships for the $\mathrm{Ni}, \mathrm{Co}$ and $\mathrm{Fe}$ (111) surfaces are similar to the DFT values. Also, as shown before [39], the activation energies predicted by the BEP relationship for the $\mathrm{CH} \rightarrow \mathrm{C}+\mathrm{H}$ combustion reaction on the $\mathrm{Ni}, \mathrm{Co}$ and $\mathrm{Fe}$ surfaces are $1.20,1.08$ and $0.83 \mathrm{eV}$, respectively, which can be compared to the explicit DFT energies of 1.23, 1.08 and $0.79 \mathrm{eV}$. Similarly, the transition state energies predicted by the TSS relationship for this reaction are $-69.70,-87.93$ and $-92.45 \mathrm{eV}$ on the $\mathrm{Ni}, \mathrm{Co}$ and Fe surfaces, respectively, which can be compared to the explicit DFT energies of $-69.98,-87.88$ and $-92.57 \mathrm{eV}$, respectively. The average difference between the BEP-predicted $\mathrm{E}_{\mathrm{a}}$ for all six synthesis and combustion reactions and the DFT-calculated $\mathrm{E}_{\mathrm{a}}$ is $17.65 \%$, with the best agreement for $\mathrm{CH} \rightarrow \mathrm{C}+\mathrm{H}$ reaction on the Co surface with an error of $0.15 \%$ and the worst for the $\mathrm{CHO} \rightarrow \mathrm{CO}+\mathrm{H}$ reaction on Co with an error of $89.47 \%$.

There is only a $0.39 \%$ average difference between TSSpredicted $\mathrm{E}_{\mathrm{TS}}$ and the DFT-calculated $\mathrm{E}_{\mathrm{TS}}$. The best agreement is for the $\mathrm{CO}+\mathrm{H} \rightarrow \mathrm{CHO}$ reaction on the Co surface with error of $0.02 \%$ and the worst for the $\mathrm{CHO} \rightarrow \mathrm{CH}+\mathrm{O}$ reaction on $\mathrm{Ni}$ with an error of $1.13 \%$.

The $R^{2}$ values obtained for the BEP and TSS relationships (Fig. 3) and the average differences between the DFT-calculated values and the BEP- or TSS-predicted values, show that the TSS relationship appears to be a better predictor than the BEP relationship. Moreover, the TSS relationship may be preferred since the structure of either the final or initial state, and not both, is sufficient for estimating the activation barrier.

It may be noted that the BEP and TSS relationships were derived from DFT data obtained for the reactions on the surfaces of diamagnetic metals (Ag, $\mathrm{Au}, \mathrm{Al}, \mathrm{Cu}, \mathrm{Rh}, \mathrm{Pt}$ and $\mathrm{Pd})$ and that they are used to test the resulting predictions for reactions on the surfaces of paramagnetic metals. The different magnetisms of these metals were taken into account in the calculations (by using ISPIN $=1$ for the diamagnetic metals and ISPIN $=2$ for the paramagnetic metals). In spite of this difference between the sampling and test groups, the predictions are very good. One can therefore expect the predictions made for other diamagnetic metals would be at least as good as the results presented here.

\subsection{Analysis of trends in the adsorption and activation energies}

The d-band centre, which demonstrates the ability to eject an electron from the d-band of the metal to the adsorbate, is obtained from the distribution of the surface electronic energy levels [68, 69]. It is calculated from the projected density of states (PDOS) of the d-orbitals and can be used to measure the proximity of the d-electrons to the Fermi level. It is a common way to try to understand trends in adsorption and activation energies of different metal 
(A)

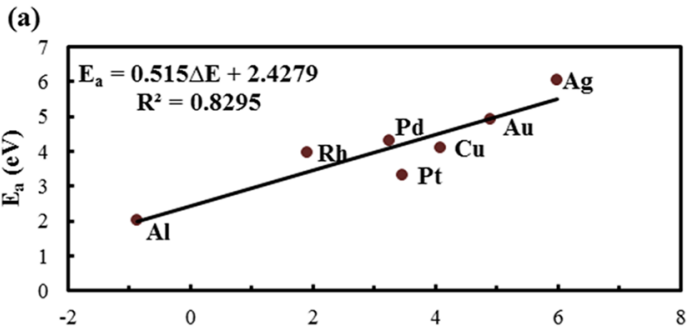

(c)

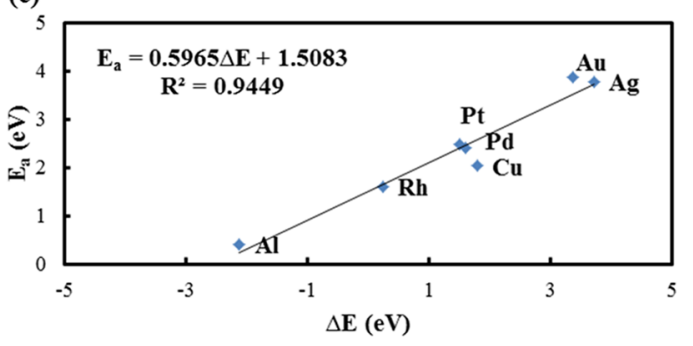

(b)

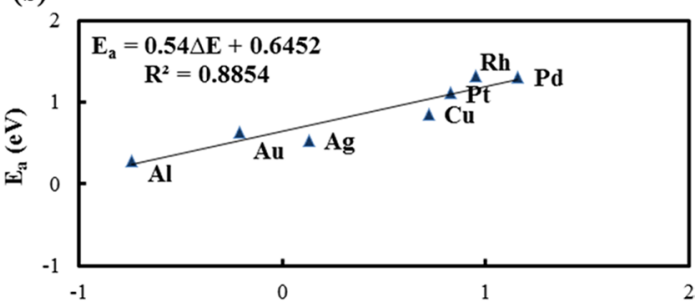

(d)

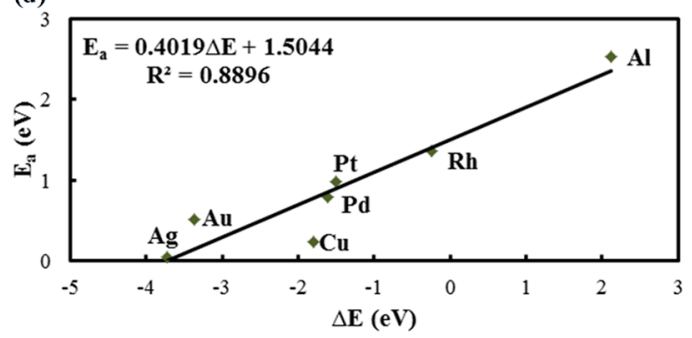

(e)

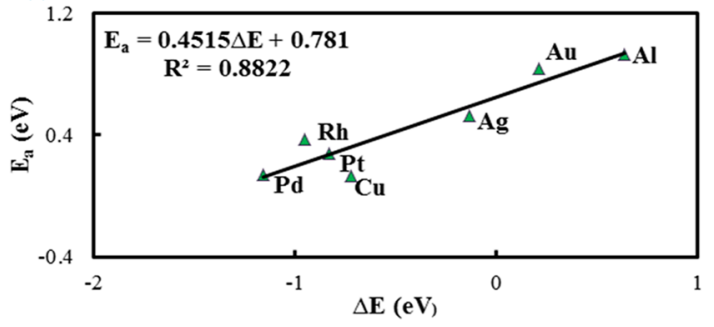

(B)

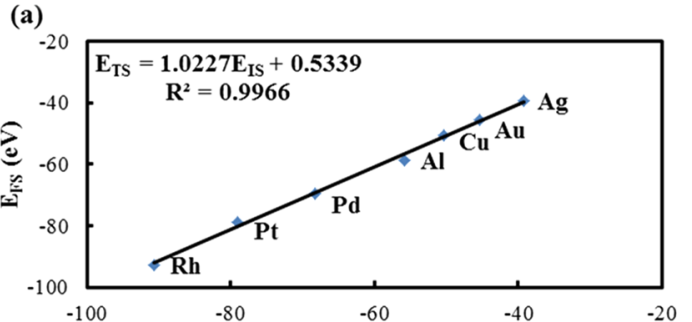

(b)

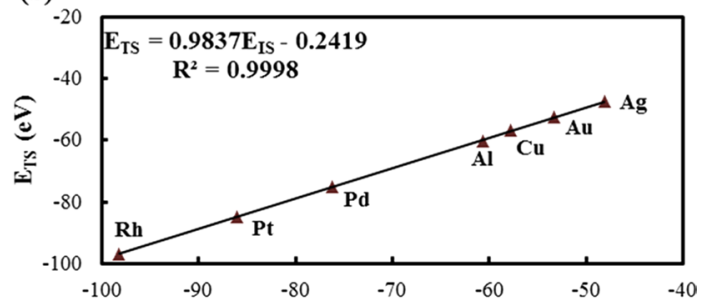

(c)

(d)
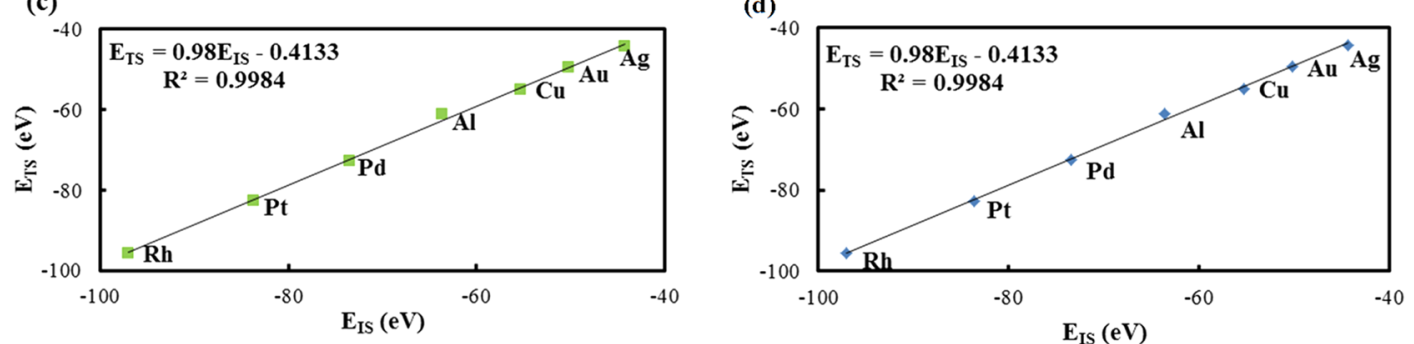

(e)

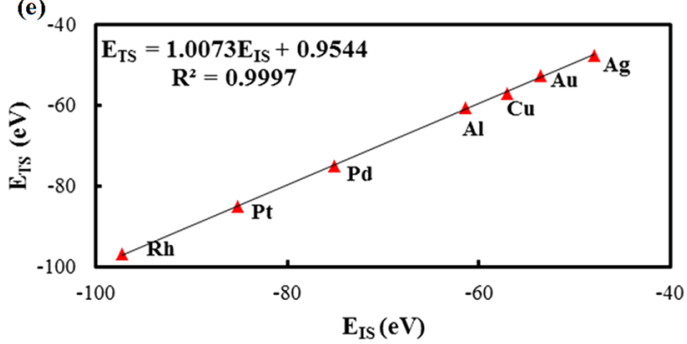


4 Fig. 3 (A) BEP and (B) TSS relationships for the a $\mathrm{CO} \rightarrow \mathrm{C}+\mathrm{O}$, b $\mathrm{CO}+\mathrm{H} \rightarrow \mathrm{CHO}$, c $\mathrm{CHO} \rightarrow \mathrm{CH}+\mathrm{O}, \mathrm{d} \mathrm{CH}+\mathrm{O} \rightarrow \mathrm{CHO}$ and e $\mathrm{CHO} \rightarrow \mathrm{CO}+\mathrm{H}$ reactions on the metallic surfaces listed in Table 1

surfaces. The projected density of states was calculated for the upper atomic layer of the metal surfaces studied here, and the results are given in Fig. S1 in supporting information. According to this figure, the adsorption energies would expect to decrease in the order $\mathrm{Au}>\mathrm{Ag}>\mathrm{Cu}>\mathrm{Pd}>\mathrm{Pt}$ $>\mathrm{Rh}$. This is different to the ordering of the adsorption and activation energies of reactant, product and the transition states given above and hence does not explain the trends seen in this work. For example, the activation energies for the $\mathrm{CH}+\mathrm{O} \rightarrow \mathrm{CHO}$ reaction decrease in the order $\mathrm{Al}>\mathrm{Rh}$ $>\mathrm{Pt}>\mathrm{Pd}>\mathrm{Au}>\mathrm{Cu}>\mathrm{Ag}$. Similar results are reported in previous studies. For example, Fajin et al. [68] reported that the d-band model cannot be used to understand the origin of the BEP relationship of water dissociation on different metal surfaces.

Another way to explain trends in adsorption and activation energies is the coordination number of the metal surface atoms. It is argued that adsorbates typically bind more strongly to surfaces with low coordination numbers [70-72]. Since the coordination numbers for all (111) surfaces studied here are identical, this is not able to explain the trends seen in the present work.

\section{Conclusions}

The thermodynamic and catalytic activity of $\mathrm{Ag}, \mathrm{Au}, \mathrm{Al}$, $\mathrm{Cu}, \mathrm{Rh}, \mathrm{Pt}$ and $\mathrm{Pd}$ (111) metal surfaces for hydrocarbon synthesis and combustion has been examined using DFT calculations based on the RPBE functional. The results have been used to test the validity of the BEP and TSS relationships for these reactions on these metal surfaces. The BEP relationship appears to be an adequate indicator for the synthesis reactions with $R^{2}$ values of $0.83,0.88$ and 0.94 for $\mathrm{CO}$ dissociation, $\mathrm{CO}$ hydrogenation and $\mathrm{CHO}$ dissociation to $\mathrm{CH}+\mathrm{O}$. In addition to the $\mathrm{CH} \rightarrow \mathrm{C}+\mathrm{H}$ combustion reaction, which has been studied previously [39], the BEP relationship also appears to be valid for the $\mathrm{CH}+\mathrm{O} \rightarrow \mathrm{CHO}$ and $\mathrm{CHO} \rightarrow \mathrm{CO}+\mathrm{H}$ combustion reactions with $R^{2}$ values of 0.89 and 0.88 , respectively. It was also found that the TSS relationship is an excellent indicator with an $R^{2}$ value of 1 for all synthesis and combustion reactions.

The BEP and TSS relationships were subsequently used to estimate the energetics of the synthesis and combustion reactions on $\mathrm{Ni}, \mathrm{Co}$ and $\mathrm{Fe}$ (111) surfaces. As expected, the energies predicted by the TSS relationship are more accurate (closer to the DFT calculations) than those predicted by the BEP relationship. In fact, there is only a $0.39 \%$ average difference between TSS-predicted transition state and the DFT-calculated values, where this average is over all synthesis and combustion reactions and all three metal surfaces. This indicates that the TSS relationship can be used to predict transition state energetics for these reactions on these surfaces without doing the time-consuming transition state DFT calculations.

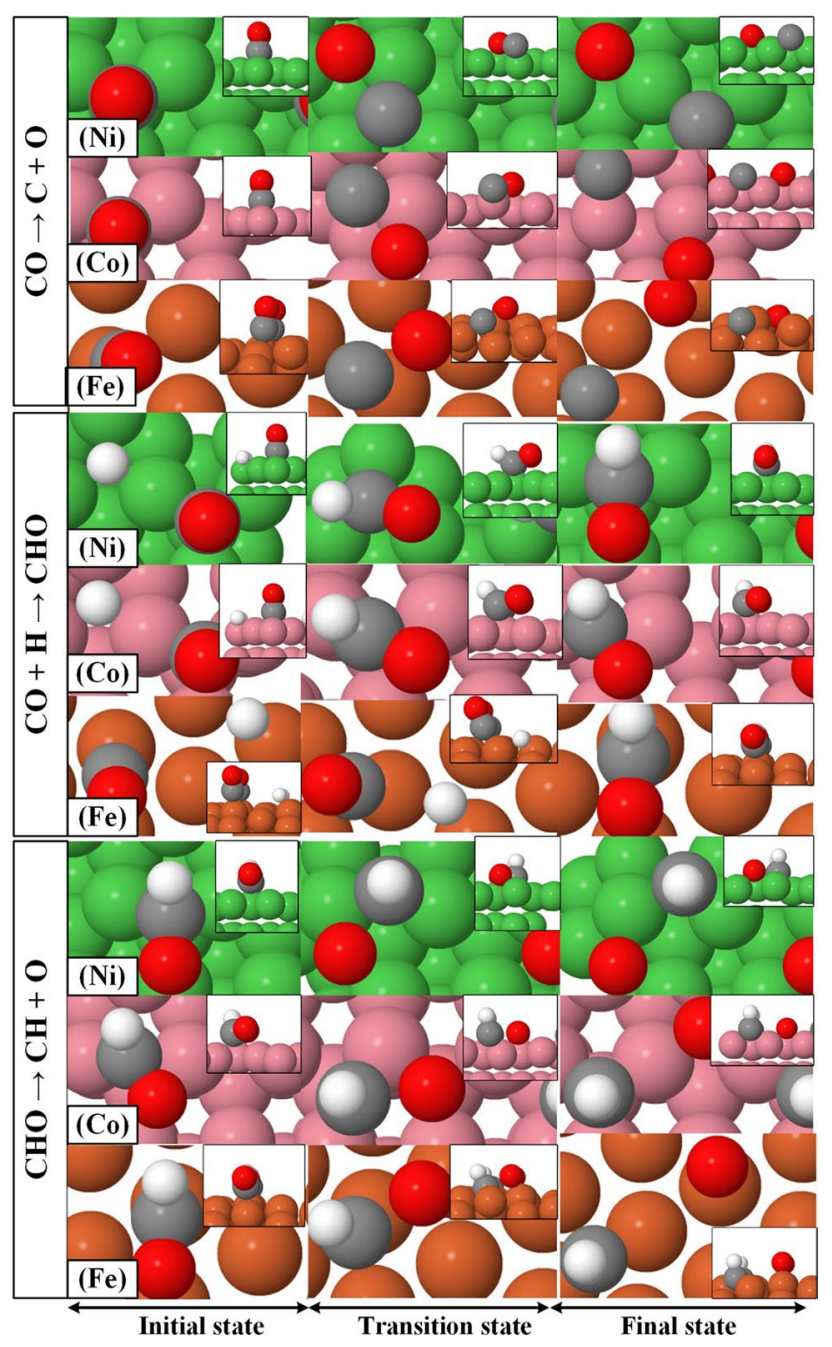

Fig. 4 Optimized structures for the initial, transition and final states for the synthesis reactions on the $\mathrm{Ni}, \mathrm{Co}$ and $\mathrm{Fe}$ (111) surfaces 
Table 4 BEP-predicted $E_{\mathrm{a}}$, TSS-predicted $E_{\mathrm{TS}}$ and the corresponding energies explicitly calculated from DFT using the methods described in Sect. 2. All energies are in $\mathrm{eV}$

\begin{tabular}{cllllll}
\hline & Reaction & Surface & $\begin{array}{l}\text { BEP- } \\
\text { predicted } \\
E_{\mathrm{a}}\end{array}$ & TSS-predicted $E_{\mathrm{TS}}$ & $\begin{array}{l}\text { DFT-cal- } \\
\text { culated } \\
E_{\mathrm{a}}\end{array}$ & DFT-calculated $E_{\mathrm{TS}}$ \\
\hline $\begin{array}{c}\text { Catalytic } \\
\text { hydro- }\end{array}$ & $\mathrm{CO} \rightarrow \mathrm{C}+\mathrm{O}$ & $\mathrm{Ni}$ & 3.49 & -71.90 & 3.30 & -72.43 \\
$\begin{array}{c}\text { carbon } \\
\text { synthesis }\end{array}$ & & $\mathrm{Co}$ & 3.11 & -89.96 & 2.61 & -90.73 \\
& $\mathrm{CO}+\mathrm{H} \rightarrow \mathrm{CHO}$ & $\mathrm{Ni}$ & 2.70 & -94.34 & 2.26 & -95.35 \\
& & $\mathrm{Co}$ & 1.38 & -78.45 & 1.52 & -77.95 \\
& & $\mathrm{Fe}$ & 0.96 & -99.78 & 1.31 & -95.76 \\
& $\mathrm{CHO} \rightarrow \mathrm{CH}+\mathrm{O}$ & $\mathrm{Ni}$ & 1.75 & -76.01 & 1.19 & -99.99 \\
& & $\mathrm{Co}$ & 1.22 & -94.15 & 0.76 & -76.87 \\
& & $\mathrm{Fe}$ & 1.75 & -99.11 & 0.94 & -99.67 \\
$\begin{array}{c}\text { Catalytic } \\
\text { hydro- }\end{array}$ & $\mathrm{CH}+\mathrm{O} \rightarrow \mathrm{CHO}$ & $\mathrm{Ni}$ & 1.34 & -76.57 & 0.84 & -76.87 \\
$\begin{array}{c}\text { carbon } \\
\text { combus- }\end{array}$ & & $\mathrm{Co}$ & 1.70 & -94.75 & 1.24 & -95.02 \\
tion & $\mathrm{CHO} \rightarrow \mathrm{CO}+\mathrm{H}$ & $\mathrm{Ni}$ & 0.16 & -77.73 & 0.16 & -77.95 \\
& & $\mathrm{Co}$ & 0.19 & -95.52 & 0.02 & -95.76 \\
& & $\mathrm{Fe}$ & 0.52 & -100.38 & 0.61 & -99.99 \\
\hline
\end{tabular}

Acknowledgements The authors are very grateful for funding from Sparbanksstiftelsen Sjuhärad. The calculations were performed on resources provided by the Swedish National Infrastructure for Computing (SNIC) at the Uppsala Multidisciplinary Centre for Advanced Computational Science (UPPMAX).

Open Access This article is distributed under the terms of the Creative Commons Attribution 4.0 International License (http://creativeco mmons.org/licenses/by/4.0/), which permits unrestricted use, distribution, and reproduction in any medium, provided you give appropriate credit to the original author(s) and the source, provide a link to the Creative Commons license, and indicate if changes were made.

\section{References}

1. Lewis SP, Rappe AM (1999) Structural and vibrational properties of carbon monoxide adlayers on the copper (001) surface. J Chem Phys 110(9):4619-4633

2. Gajdoš M, Eichler A, Hafner J (2004) CO adsorption on closepacked transition and noble metal surfaces: trends from ab initio calculations. J Phys: Condens Matter 16(8):1141

3. Meunier FC, Reid D, Goguet A, Shekhtman S, Hardacre C, Burch R, Deng W, Flytzani-Stephanopoulos M (2007) Quantitative analysis of the reactivity of formate species seen by DRIFTS over a $\mathrm{Au} / \mathrm{Ce}$ (La) O2 water-gas shift catalyst: first unambiguous evidence of the minority role of formates as reaction intermediates. J Catal 247(2):277-287

4. Hirano H, Tanaka K-I (1992) A reason for the structure-insensitive catalytic activity of $\mathrm{Ni}(100)$ and $\mathrm{Ni}$ (111) surfaces for the methanation reaction of CO. J Catal 133(2):461-466

5. Ledentu V, Dong W, Sautet P (2000) Heterogeneous catalysis through subsurface sites. J Am Chem Soc 122(8):1796-1801

6. Hirano H, Tanaka K (1993) Structure and reactivity of carbidic intermediates for the methanation reaction on $\mathrm{Ni}$ (100), $\mathrm{Ni}$ (111) and Ni (110) surfaces. Stud Surf Sci Catal 75:1575-1578
7. Hammer B, Morikawa Y, Nørskov JK (1996) CO chemisorption at metal surfaces and overlayers. Phys Rev Lett 76(12):2141

8. Kresse G, Gil A, Sautet P (2003) Significance of single-electron energies for the description of CO on Pt (111). Phys Rev B 68(7):073401

9. Thiel PA, Madey TE (1987) The interaction of water with solid surfaces: fundamental aspects. Surf Sci Rep 7(6-8):211-385

10. Nöbl C, Benndorf C, Madey TE (1985) $\mathrm{H}_{2} \mathrm{O}$ adsorption on $\mathrm{Ni}$ (100): evidence for oriented water dimers. Surf Sci 157(1):29-42

11. Bunnik BS, Kramer GJ (2006) Energetics of methane dissociative adsorption on Rh 111 from DFT calculations. J Catal 242(2):309-318

12. Fischer F, Tropsch H (1923) The preparation of synthetic oil mixtures (synthol) from carbon monoxide and hydrogen. BrennstChem 4:276-285

13. Zhuo M, Tan KF, Borgna A, Saeys M (2009) Density functional theory study of the CO insertion mechanism for Fischer-Tropsch synthesis over Co catalysts. J Phys Chem C 113(19):8357-8365

14. Cheng J, Hu P, Ellis P, French S, Kelly G, Lok CM (2008) Chain growth mechanism in Fischer-Tropsch synthesis: a DFT study of $\mathrm{C}-\mathrm{C}$ coupling over $\mathrm{Ru}, \mathrm{Fe}, \mathrm{Rh}$, and Re surfaces. J Phys Chem C 112(15):6082-6086

15. Bromfield TC, Curulla Ferré D, Niemantsverdriet JW (2005) A DFT study of the adsorption and dissociation of $\mathrm{CO}$ on $\mathrm{Fe}(100)$ : influence of surface coverage on the nature of accessible adsorption states. ChemPhysChem 6(2):254-260

16. Ojeda M, Nabar R, Nilekar AU, Ishikawa A, Mavrikakis M, Iglesia E (2010) CO activation pathways and the mechanism of Fischer-Tropsch synthesis. J Catal 272(2):287-297

17. Mohsenzadeh A, Bolton K, Richards T (2015) Oxidation and dissociation of formyl on $\mathrm{Ni}$ (111), Ni (110) and Ni (100) surfaces: a comparative density functional theory study. Top Catal 58(14-17):1136-1149

18. Inderwildi OR, Jenkins SJ, King DA (2007) An unexpected pathway for the catalytic oxidation of methylidyne on Rh 111 as a route to syngas. J Am Chem Soc 129(6):1751-1759

19. Yazawa Y, Takagi N, Yoshida H, S-i Komai, Satsuma A, Tanaka T, Yoshida S, Hattori T (2002) The support effect on propane combustion over platinum catalyst: control of the oxidation-resistance 
of platinum by the acid strength of support materials. Appl Catal A 233(1-2): 103-112

20. Gomes JRB, Gomes J (2000) Adsorption of the formyl species on transition metal surfaces. J Electroanal Chem 483(1):180-187

21. Inderwildi OR, Jenkins SJ, King DA (2008) Mechanistic studies of hydrocarbon combustion and synthesis on noble metals. Angew Chem Int Ed 47(28):5253-5255

22. Zhao YH, Sun K, Ma X, Liu J, Sun D, Su HY, Li WX (2011) Carbon chain growth by formyl insertion on rhodium and cobalt catalysts in syngas conversion. Angew Chem Int Ed 50(23):5335-5338

23. Zhu Y-A, Chen D, Zhou X-G, Yuan W-K (2009) DFT studies of dry reforming of methane on $\mathrm{Ni}$ catalyst. Catal Today 148(3):260-267

24. Mehmood F, Kara A, Rahman TS, Bohnen KP (2006) Energetics of $\mathrm{CO}$ on stepped and kinked $\mathrm{Cu}$ surfaces: a comparative theoretical study. Phys Rev B 74(15):155439

25. Remediakis IN, Abild-Pedersen F, Nørskov JK (2004) DFT study of formaldehyde and methanol synthesis from $\mathrm{CO}$ and H2 on Ni (111). J Phys Chem B 108(38):14535-14540

26. Grabow LC, Studt F, Abild-Pedersen F, Petzold V, Kleis J, Bligaard T, Nørskov JK (2011) Descriptor-based analysis applied to $\mathrm{HCN}$ synthesis from $\mathrm{NH} 3$ and $\mathrm{CH} 4$. Angew Chem Int Ed 50(20):4601-4605

27. Nørskov JK, Bligaard T, Logadottir A, Bahn S, Hansen LB, Bollinger M, Bengaard H, Hammer B, Sljivancanin Z, Mavrikakis M (2002) Universality in heterogeneous catalysis. J Catal 209(2):275-278

28. Pallassana V, Neurock M (2000) Electronic factors governing ethylene hydrogenation and dehydrogenation activity of pseudomorphic PdML/Re (0001), PdML/Ru (0001), Pd (111), and PdML/Au (111) surfaces. J Catal 191(2):301-317

29. Liu Z-P, Hu P (2001) General trends in CO dissociation on transition metal surfaces. J Chem Phys 114(19):8244-8247

30. Logadottir A, Rod TH, Nørskov JK, Hammer B, Dahl S, Jacobsen CJH (2001) The Brønsted-Evans-Polanyi relation and the volcano plot for ammonia synthesis over transition metal catalysts. J Catal 197(2):229-231

31. Fajín JLC, Cordeiro MNDS, Illas F, Gomes JRB (2014) Generalized Brønsted-Evans-Polanyi relationships and descriptors for $\mathrm{O}-\mathrm{H}$ bond cleavage of organic molecules on transition metal surfaces. J Catal 313:24-33

32. Abild-Pedersen F, Greeley J, Studt F, Rossmeisl J, Munter TR, Moses PG, Skulason E, Bligaard T, Nørskov JK (2007) Scaling properties of adsorption energies for hydrogen-containing molecules on transition-metal surfaces. Phys Rev Lett 99(1):016105

33. Santen RAV, Neurock M, Shetty SG (2009) Reactivity theory of transition-metal surfaces: a Brønsted-Evans-Polanyi linear activation energy-free-energy analysis. Chem Rev 110(4):2005-2048

34. Liao M-S, Zhang Q-E (1998) Dissociation of methane on different transition metals. J Mol Catal A: Chem 136(2):185-194

35. Lin C-H, Chen C-L, Wang J-H (2011) Mechanistic studies of water-gas-shift reaction on transition metals. J Phys Chem C 115(38):18582-18588

36. Neef M, Doll K (2006) CO adsorption on the $\mathrm{Cu}$ (111) surface: a density functional study. Surf Sci 600(5):1085-1092

37. Vollmer S, Witte G, Wöll C (2001) Determination of site specific adsorption energies of $\mathrm{CO}$ on copper. Catal Lett 77(1):97-101

38. Huang S-C, Lin C-H, Wang JH (2010) Trends of water gas shift reaction on close-packed transition metal surfaces. J Phys Chem C 114(21):9826-9834

39. Arya M, Mirzaei AA, Davarpanah AM, Barakati SM, Atashi H, Mohsenzadeh A, Bolton K (2018) DFT studies of hydrocarbon combustion on metal surfaces. J Mol Model 24(2):47. https://doi. org/10.1007/s00894-018-3585-Z

40. Kresse G, Hafner J (1993) Ab initio molecular dynamics for liquid metals. Phys Rev B 47(1):558

41. Kresse G, Furthmüller J (1996) Efficiency of ab initio total energy calculations for metals and semiconductors using a plane-wave basis set. Comput Mater Sci 6(1):15-50

42. Kresse G, Furthmüller J (1996) Efficient iterative schemes for ab initio total-energy calculations using a plane-wave basis set. Phys Rev B 54(16):11169

43. Wan JF, Wang JN (2005) Structure dependence of optical spectra of ferromagnetic Heusler alloy Ni-Mn-Ga. Physica B 355(1):172-175

44. Selvarani G, Selvaganesh SV, Krishnamurthy S, Kiruthika GVM, Sridhar P, Pitchumani S, Shukla AK (2009) A methanol-tolerant carbon-supported $\mathrm{Pt}-\mathrm{Au}$ alloy cathode catalyst for direct methanol fuel cells and its evaluation by DFT. J Phys Chem C 113(17):7461-7468

45. Termentzidis $\mathrm{K}$, Hafner $\mathrm{J}$ (2007) $\mathrm{CO}$ adsorption on a $\mathrm{Au} / \mathrm{Ni}$ (111) surface alloy—a DFT study. J Phys: Condens Matter 19(24):246219

46. Andersson MP, Bligaard T, Kustov A, Larsen KE, Greeley J, Johannessen T, Christensen CH, Nørskov JK (2006) Toward computational screening in heterogeneous catalysis: paretooptimal methanation catalysts. J Catal 239(2):501-506

47. Hammer B, Hansen LB, Nørskov JK (1999) Improved adsorption energetics within density-functional theory using revised Perdew-Burke-Ernzerhof functionals. Phys Rev B 59(11):7413

48. Blöchl PE (1994) Projector augmented-wave method. Phys Rev B 50(24):17953

49. Pan Y, Zhang H, Shi D, Sun J, Du S, Liu F, Hj Gao (2009) Highly ordered, millimeter-scale, continuous, single-crystalline graphene monolayer formed on Ru (0001). Adv Mater 21(27):2777-2780

50. Wang S-G, Cao D-B, Li Y-W, Wang J, Jiao H (2005) Chemisorption of $\mathrm{CO}_{2}$ on nickel surfaces. J Phys Chem B 109(40):18956-18963

51. Monkhorst HJ, Pack JD (1976) Special points for Brillouin-zone integrations. Phys Rev B 13(12):5188

52. Mohsenzadeh A, Borjesson A, Wang J-H, Richards T, Bolton $\mathrm{K}$ (2013) The effect of carbon monoxide co-adsorption on Nicatalysed water dissociation. Int J Mol Sci 14(12):23301-23314

53. Mohsenzadeh A, Richards T, Bolton K (2015) A density functional theory study of hydrocarbon combustion and synthesis on Ni surfaces. J Mol Model 21(3):46

54. Hu C, Ting S-W, Chan K-Y, Huang W (2012) Reaction pathways derived from DFT for understanding catalytic decomposition of formic acid into hydrogen on noble metals. Int J Hydrogen Energy 37(21):15956-15965

55. Henkelman G, Jónsson H (2000) Improved tangent estimate in the nudged elastic band method for finding minimum energy paths and saddle points. J Chem Phys 113(22):9978-9985

56. Henkelman G, Uberuaga BP, Jónsson H (2000) A climbing image nudged elastic band method for finding saddle points and minimum energy paths. J Chem Phys 113(22):9901-9904

57. Ciobîcă IM, Kramer GJ, Ge Q, Neurock M, Van Santen RA (2002) Mechanisms for chain growth in Fischer-Tropsch synthesis over Ru (0001). J Catal 212(2):136-144

58. Belosludov RV, Sakahara S, Yajima K, Takami S, Kubo M, Miyamoto A (2002) Combinatorial computational chemistry approach as a promising method for design of Fischer-Tropsch catalysts based on Fe and Co. Appl Surf Sci 189(3):245-252

59. Mohsenzadeh A, Richards T, Bolton K (2015) A density functional theory study of hydrocarbon combustion and synthesis on Ni surfaces. J Mol Model 21(3):1-11 
60. Fajín JLC, Cordeiro MNDS, Illas F, Gomes JRB (2009) Influence of step sites in the molecular mechanism of the water gas shift reaction catalyzed by copper. J Catal 268(1):131-141

61. Hammer B, Nørskov JK (2000) Theoretical surface science and catalysis-calculations and concepts. Adv Catal 45:71-129

62. Mason SE, Grinberg I, Rappe AM (2004) First-principles extrapolation method for accurate $\mathrm{CO}$ adsorption energies on metal surfaces. Phys Rev B 69(16):161401

63. Gokhale AA, Dumesic JA, Mavrikakis M (2008) On the mechanism of low-temperature water gas shift reaction on copper. J Am Chem Soc 130(4):1402-1414

64. Wu M, Wang X, Dai Q, Gu Y, Li D (2010) Low temperature catalytic combustion of chlorobenzene over $\mathrm{Mn}-\mathrm{Ce}-\mathrm{O} / \gamma-\mathrm{Al} 2$ O 3 mixed oxides catalyst. Catal Today 158(3):336-342

65. Li N, Gaillard F, Boréave A (2008) Electrochemical promotion of Ag catalyst for the low temperature combustion of toluene. Catal Commun 9(6):1439-1442

66. Enger BC, Holmen A (2012) Nickel and Fischer-Tropsch Synthesis. Catalysis Reviews 54(4):437-488
67. Evans MG, Polanyi M (1938) Inertia and driving force of chemical reactions. Trans Faraday Soc 34:11-24

68. Fajín JLC, Cordeiro MNDS, Illas F, Gomes JRB (2010) Descriptors controlling the catalytic activity of metallic surfaces toward water splitting. J Catal 276(1):92-100

69. Hammer B, Nørskov JK (1995) Electronic factors determining the reactivity of metal surfaces. Surf Sci 343(3):211-220

70. Lee WT, Ford L, Blowers P, Nigg HL, Masel RI (1998) Why do heats of adsorption of simple gases on platinum surfaces vary so little with surface structure? Surf Sci 416(1):141-151

71. Pang X-Y, Wang C, Zhou Y-H, Zhao J-M, Wang G-C (2010) DFT study of the structure sensitivity for the adsorption of methyl, methoxy, and formate on $\mathrm{Ni}(111), \mathrm{Ni}(100)$, and $\mathrm{Ni}$ (110) surfaces. J Mol Struct (Thoechem) 948(1):1-10

72. Delbecq F, Sautet P (1993) Low-temperature adsorption of formaldehyde on a platinum (111) surface. A theoretical study. Langmuir 9(1):197-207 